\title{
MEASURING INSTABILITY OF FOREIGN DIRECT INVESTMENT FLOWS IN LATVIA
}

\author{
Andrejs Limanskis \\ RISEBA University of Business, Arts and Technology, Latvia
}

\begin{abstract}
Fluctuations of Foreign Direct Investment (FDI) flows constitute an acute research problem globally and in Latvia studies. Already before COVID19, negative flows occurred. The research aim is to investigate stability in FDI in Latvia applying theory of dynamical system to big database of 129 countries of origin of FDI covering the whole period of regained statehood. The primary methods used are standard deviation and correlation. The main research result is disclosing growing instability of FDI flows in Latvia despite joining the EU and Eurozone. Novelty consists of research methodology justification, plotting analytical table, calculation of sigma and correlations for FDI flows for the periods before and after Latvia joined the EU, and drawing conclusions.
\end{abstract}

Keywords: correlation, deals, foreign direct investment flow, instability, investors, Latvia, standard deviation.

\section{Introduction}

Topicality: Integration of business across the borders manifests itself in foreign direct investment (FDI) flows. Merging of theories of internationalization and location is one of the most exciting opportunities for scholars and executives. The second decade of the 21st century, however, brought the need to revise the theory of cross-border corporate mobility. The USA policy shift in favour of protectionism, Brexit, closure of state borders under COVID emergencies and a number of less crucial but very spectacular trends all over the world introduced unexpected instability and even put internationalization under question. Unprecedented decline in global FDI recently is aggravating situation of instability.

Attempts to investigate instability in FDI are few. In numerous fields of study, the component of instability within a system is generally characterized by some of the outputs or internal states changing without bounds. It is a stand of a system characterised by certain indicators. To what extent is Latvia subject to FDI instability? Is FDI instability growing? 1.05.2004 Latvia joined the European Union. This factor affected FDI flows. Answer to the above questions is a precondition for measures of stabilisation. Foreseeing challenges and opportunities for business at the macro and micro level paves the way to perfection. 
Aim: to investigate stability in FDI in Latvia applying theory of dynamical systems approach, namely standard deviation (Sigma) calculation in representative sample of countries of origin.

Methods and results: For the first time, Sigmas are to be calculated for the total and five major FDI flows in Latvia. Growing FDI instability in Latvia can be proven for five countries of origin of the representative sample by comparing two sub-periods of the whole time span in line with the theory of dynamical systems. Correlational analysis deepens the research. The methodology can then be applied to all FDI flows. Further research directions will be substantiated

\section{Literature Review}

Literature on FDI is immense. Stakeholders are worried about the current instability of flows of FDI. But attempts to investigate instability in FDI are few. Among partisans of sustainability as mainstream it is believed (Leal Filho et al., 2021) that sustainable development research suffers under global Covid-19 crisis. FDI expert stated, "Global FDI plummeted to historic lows in 2020 as Covid-19 forced investors to push the brakes on expansion plans" (Dettoni, 2021).

In the Baltics, A. Sauka has initiated FDI Index the popularity of which goes beyond foreign investors (Sauka, 2020). D. Pelēce provides macroeconomic description of FDI in Latvia (Pelēce, 2020). But as concerns FDI instability per se, no research models or calculations are present.

It means that insecurity and unsteadiness of FDI are not expressed in figures and remain only as anticipated phenomena or a number of cases.

Oxford dictionary defines instability as ,the state of being unstable; lack of stability”, as well as ,tendency to unpredictable behaviour or erratic changes of mood" (Oxford dictionary, 2020).

Wider understanding of instability is given by Cambridge dictionary as „uncertainty caused by the possibility of a sudden change in the present situation: political/economic instability, the instability of the euro" (Cambridge Dictionary, 2020).

In the theory of dynamical systems, a state variable in a system is said to be unstable if it evolves without bounds. A system itself is said to be unstable if at least one of its state variables is unstable. In business, it creates uncertainty as opposed to the desired fastness, fixedness, security, stability, and steadiness.

C. Granger has noted that at any given time, a dynamical system has a state given by a tuple of real numbers (a vector) that can be represented by a point in an appropriate state space (a geometrical manifold) (Granger, 1994). The evolution rule of the dynamical system is a function that describes what future states follow from the current state. Often the function is deterministic, that is, for a given time interval only one future state follows from the current state. However, 
some systems are stochastic, in that random events also affect the evolution of the state variables.

G. Gandolfo laid the foundations for dynamic economic theory and gave a push to its applications to a wide variety of fields, including economics (Gandolfo, 2009). Dynamical systems are a fundamental part of chaos theory, logistic map dynamics, bifurcation theory, the self-assembly process, and the edge of chaos concept.

The definition of instability by Your Dictionary as „lack of stability or balance, or a tendency towards unpredictable or erratic behaviour" (Your Dictionary, 2020) adds another shade in the notion. In FDI, unpredictable or erratic behaviour is to be avoided due to immense economic, social and political effect.

\section{Methodology}

Electronic data capture, according to research methodologists is „a method for collecting data entered directly into a computer" (Research methodologists adphealth, 2020). It belongs to quantitative data collection tools. Registration of FDI deals by Register of enterprises of Latvian Republic secures objective selection of top five FDI flows by counrties of origin in Latvia and their comparative study for the whole period of transition from commandoadministrative to market economy. Thus the way is paved to plotting a set of analytical tables of basic characteristics of FDI in Latvia in total and by the five focus countries. Time series analysis, calculation of Standard deviations, or Sigmas, as well as Sigma to Average FDI by period is to give answer on the question Is instability in FDI flows in Latvia growing? The higher the stability of a certain donor country FDI, the closer its correlation should be with the total FDI.

Standard deviation is known to be calculated based on the mean. The distance of each data point from the mean is squared, summed and averaged to find the variance. Standard deviation is the square root of the variance.

The standard deviation is calculated using (Mathisfun, 2020) Formula 1:

$$
\begin{aligned}
& \sigma=\sqrt{\frac{\sum(X-\mu)^{2}}{n}} \\
& \text { where, } \\
& \begin{aligned}
\sigma & =\text { population standard deviation } \\
\sum & =\text { sum of... } \\
\mu & =\text { population mean } \\
\mathrm{n} & =\text { number of scores in sample. }
\end{aligned}
\end{aligned}
$$


Accumulation of big databases proves precondition for application of the above methodology. The most reliable statistics in FDI is made public by Lursoft. Selection of countries of origin of FDI in Latvia for the research based on biggest accumulated investments in the statutory capital and highlighted Sweden, Russia, the Netherlands, Cyprus and Lithuania. Sub-dividing the time span of all 28 years in two parts for comparison is proposed for FDI in Latvia deals statistics due to importance of joining the EU by Latvia.

If the data points are further from the mean, there is higher deviation within the data set; thus, the more spread out the data, the higher the standard deviation. Author came across no attempts in the literature to apply the theory to FDI flows.

The correlation coefficient is a statistical measure of the strength of the relationship between the relative movements of two variables. In FDI analysis the total and specific volumes of donor countries can correlate. The values range between -1.0 and 1.0 .

In this research, sigma is selected to be employed as FDI instability indicator. To go deeper, relations of the sigma to average investment if measured at different time points can give more evidence of growing/decreasing instability in FDI flows. Thus followers are invited to deepen into FDI analysis by countries, time spans, industries, etc.

\section{Research Results}

Author plotted a complete set of analytical tables of basic characteristics of FDI in Latvia for the total of all 129 countries and by the five focus countries with permission by Lursoft. It embraces all FDI deals in the statutory capital of enterprises from the first registrations in the Register of Enterprises of Latvian Republic in 1991 to the cut-off date of this research 31.12.2019.

Table 1 Foreign Direct Investments in Latvia 1991-2019

\begin{tabular}{|l|l|l|l|}
\hline \multicolumn{1}{|c|}{ Country } & Deals & Investments, EUR & Date \\
\hline Sweden & 703 & 1104644 375,34 & 05.02 .1991 \\
\hline Russian Federation & 5879 & 685863564,09 & 04.03 .1991 \\
\hline The Netherlands & 439 & 633703559,86 & 20.03 .1991 \\
\hline Cyprus & 668 & 602028801,19 & 16.12 .1991 \\
\hline Lithuania & 2682 & 556702890,55 & 06.03 .1991 \\
\hline Top 5 & 10371 & 3582943191,03 & \\
\hline All 129 & $\mathbf{2 5 9 4 7}$ & $\mathbf{6 9 8 9} \mathbf{9 1 7 6 0 0 , 7 7}$ & \\
\hline
\end{tabular}

Source: Lursoft 
It can be observed in the table that around seven billion euro have been accumulated as FDI in Latvia in 1991-2019. The top five can be selected as a representative sample, because the top five account for above 51,2\% of total FDI in Latvia by investors from 129 countries.

As already mentioned, Latvia joined the EU 1.05.2004. Since then until 2016 there were only positive yearly saldos of inflows and outflows of FDI in this country. Unfortunately, in 2016, the decline started. It was not stopped in 2017 2019 (see Fig.1).

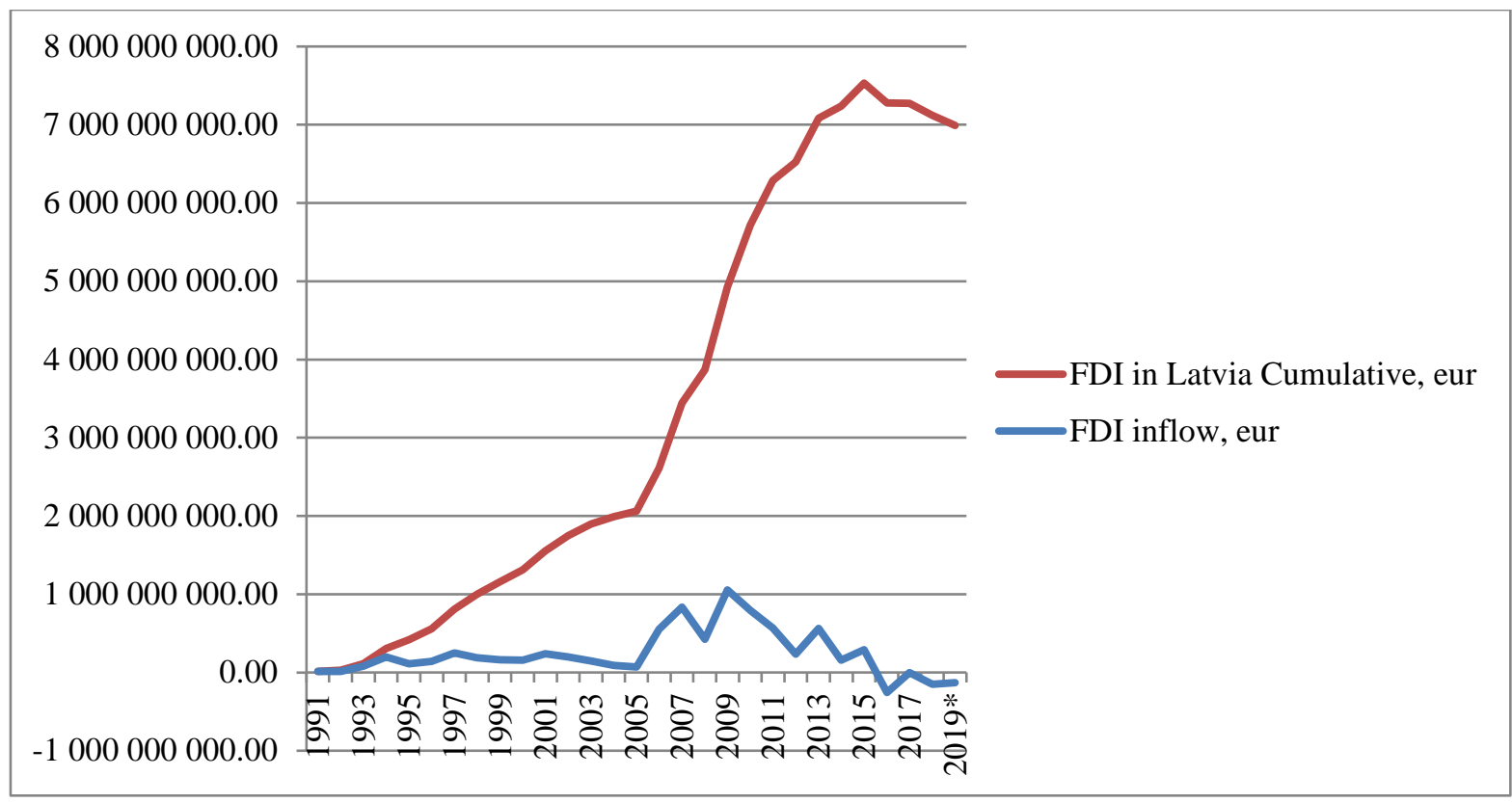

Figure 1 FDI in Latvia Cumulative and Yearly Flows, EUR (Lursoft)

It is noticeable on the linear chart that a breaking point is the year 2005 after which FDI flow jumped tenfold in two years, then decreased almost by half, from $834 \mathrm{mln}$ to $425 \mathrm{mln}$ euro, then more than doubled to break through 1 bln all-time record in order to fall again almost by half. It even went in the negative zone in 2016, 2017 and 2018. The cumulative figure started to decline since 2015.

For research in instability, author suggested two periods for calculation and comparison of Sigma, namely 1991-2004 and 2005-2019. It happens that the number of years is equal in the each of the two time spans (14 years).

Sigma for all 30 years is 36282078482,35 euro, for the first 14 years 14 080638 020,06 euro and for the recent 14 years 49340795 199,78 euro. In the recent time span (2005-2019) the monetary sigma is 3.5 times higher against the one of the previous period 1991-2004.

Average FDI per project was calculated by Author and analysed by countries of origin (see fig.2) 


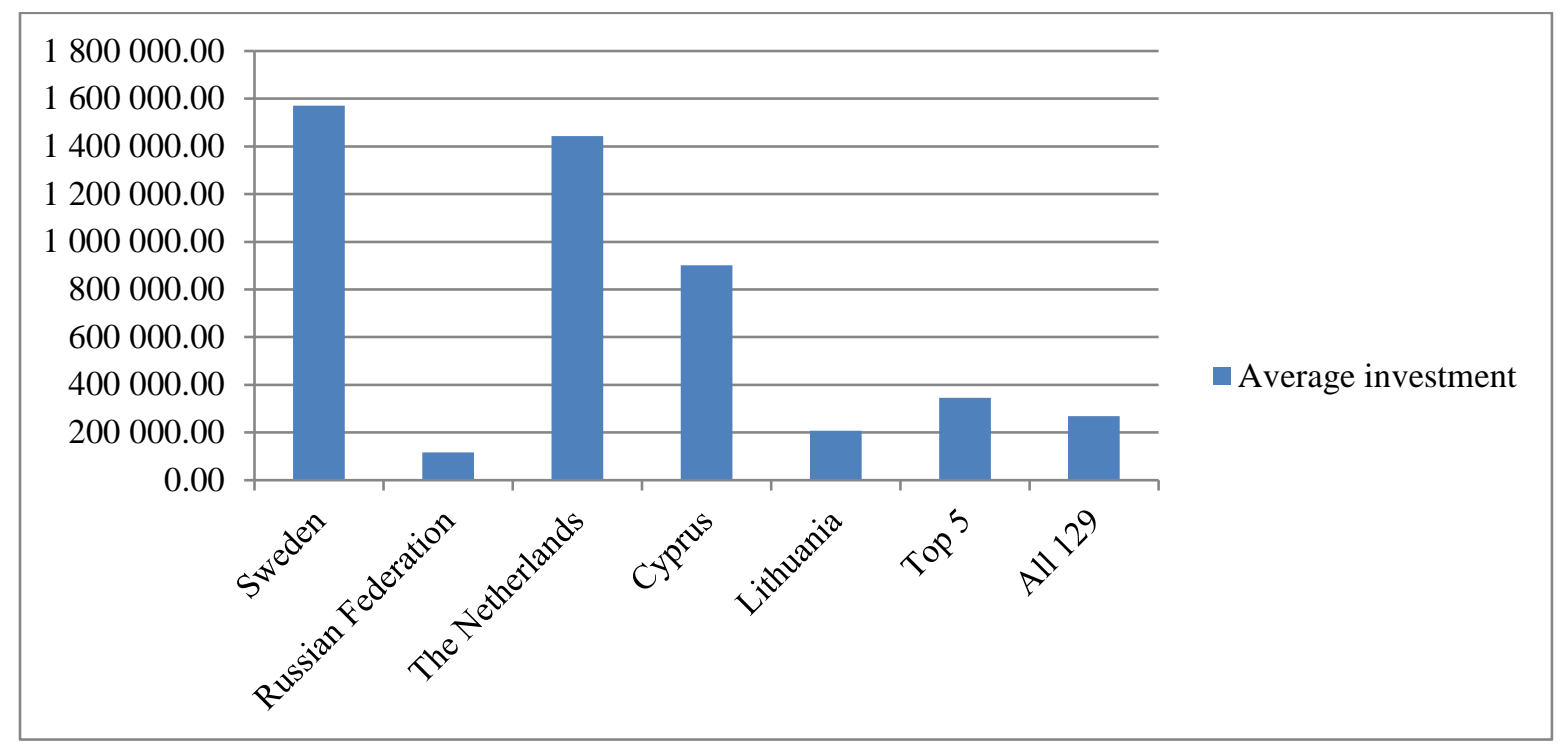

Figure 2 Average FDI in Latvia by Country of Origin, 1991-2019, EUR (author on the basis of Lursoft)

For the top five, the average FDI in Latvia proves 1.27 times higher against that for all 129 countries of origin (345 mln euro against 269). For Sweden, the Netherlands and Cyprus the average is higher and for Russia and Lithuania is lower. The average figures can be taken for calculation of indicators of FDI instability in the future research as the time series increase.

The FDI in Latvia statistics for each of the five selected countries of origin is analysed lower. Author plotted charts in such a way that both cumulative and yearly flows could be investigated. The first is analysis of FDI in Latvia from Sweden as the clear leader (see Fig. 3).

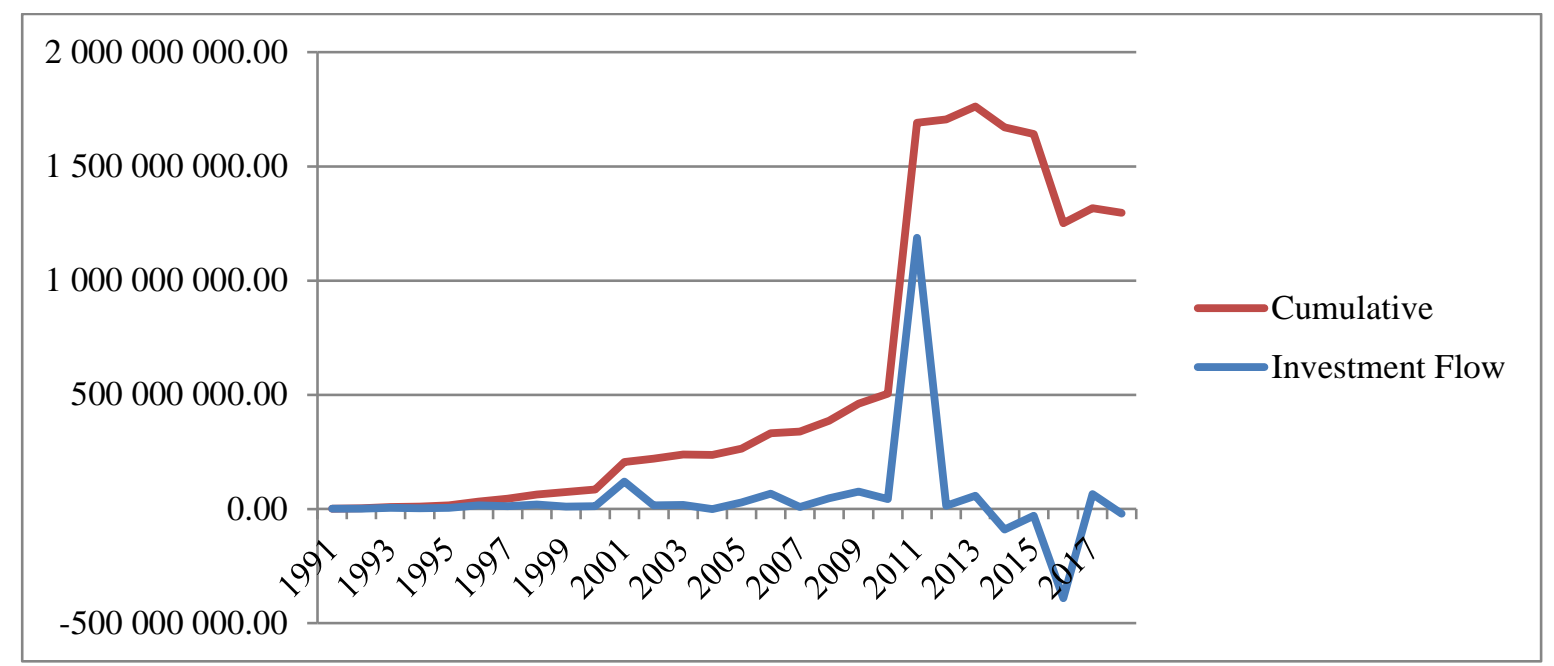

Figure 3 Sweden FDI in Latvia Cumulative and Yearly Flow, EUR (Lursoft) 
Jump in 2011 by 1,187,122,679 euro was mainly caused by notable investment in Swedbank Latvia by Swedbank AB as lump sum of 942,853,584 euro registered 01.07.2011. The same year, record investment in Sodra Latvia was undertaken by Bergvik Skog $\mathrm{AB}$ as a sum of 41,737,241 euro registered 28.11.2011.

For FDI from Sweden in Latvia, Sigma for the whole period 239808 034,25 euro, for the years 1991-2004 33760 697,93 euro and for the years 2005-2019 337455 184,96 euro.

Increase of FDI instability is evident for the leading country of origin in this research.

Following is analysis of FDI in Latvia from Russia (see Fig. 4).

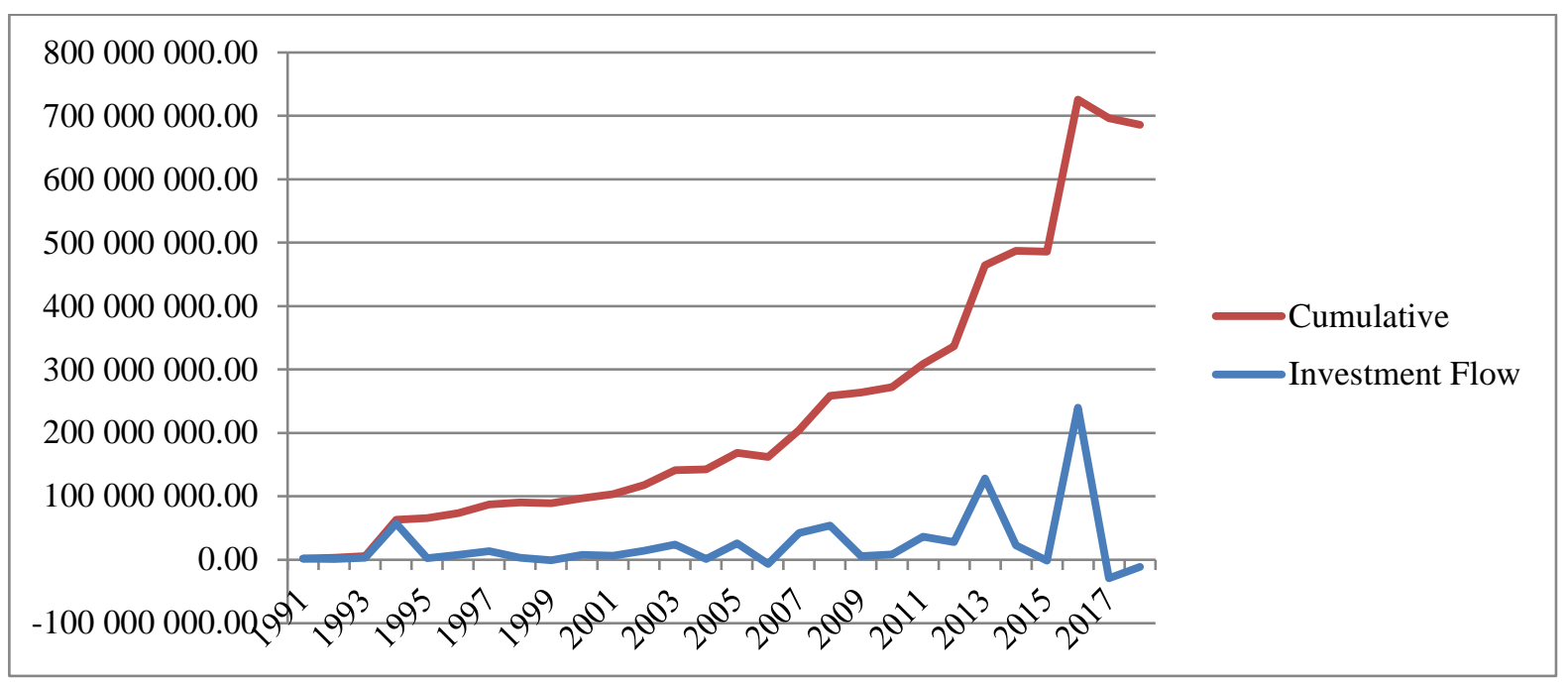

Figure 4 Russian Federation FDI in Latvia Cumulative and Yearly Flow, EUR (Lursoft)

In 2016, when the total FDI in Latvia started to diminish, JP Termināls SIA received from the investor Eclipse petroleum Limider a record sum of 160,000,008.00 euro registered 14.06.2016. Some threee month earlier, Severstal Distribution SIA enjoyed investment from SEVERSTAL, Public Joint Venture of $51,993,613.00$ euro registered 16.03.2016. One more deal to mention is investment in PNB Banka AS by investor Guselnikov Grigory of 8,267,396.00 euro registered 31.12.2016.

In 2017, a record withdrawal of 29,133,138.00 euro of FDI belonging to investors from Russia was registered mainy as result of withdrawal of 24,161,690 euro 28.03.2017 and 16,641,520 euro 30.09.2017 from Signet Bank by investor Vdovin A. The withdrawal was not compensated by his investing in the same bank of 24,000,000.00 euro that occured 04.08.2017. To mention is interplay of 40 million euro investments by investor Sternfeld V. registered 6.01.2017 and 
4.08.2017 with withdrawal of the same 40 million in sudden liquidation of his enterprise in Latvia 15.12.2017.

Sigma for FDI flow from Russian Federation for the whole period 2628962 056156270 euro, for the years 1991-2004 75708 431,74 euro and for the years 2005-2019 255441 204,35 euro.

Increase of FDI instability is evident for the second leading country of origin in this research. Following is analysis of FDI in Latvia from the third leader the Netherlands (see Fig. 5).

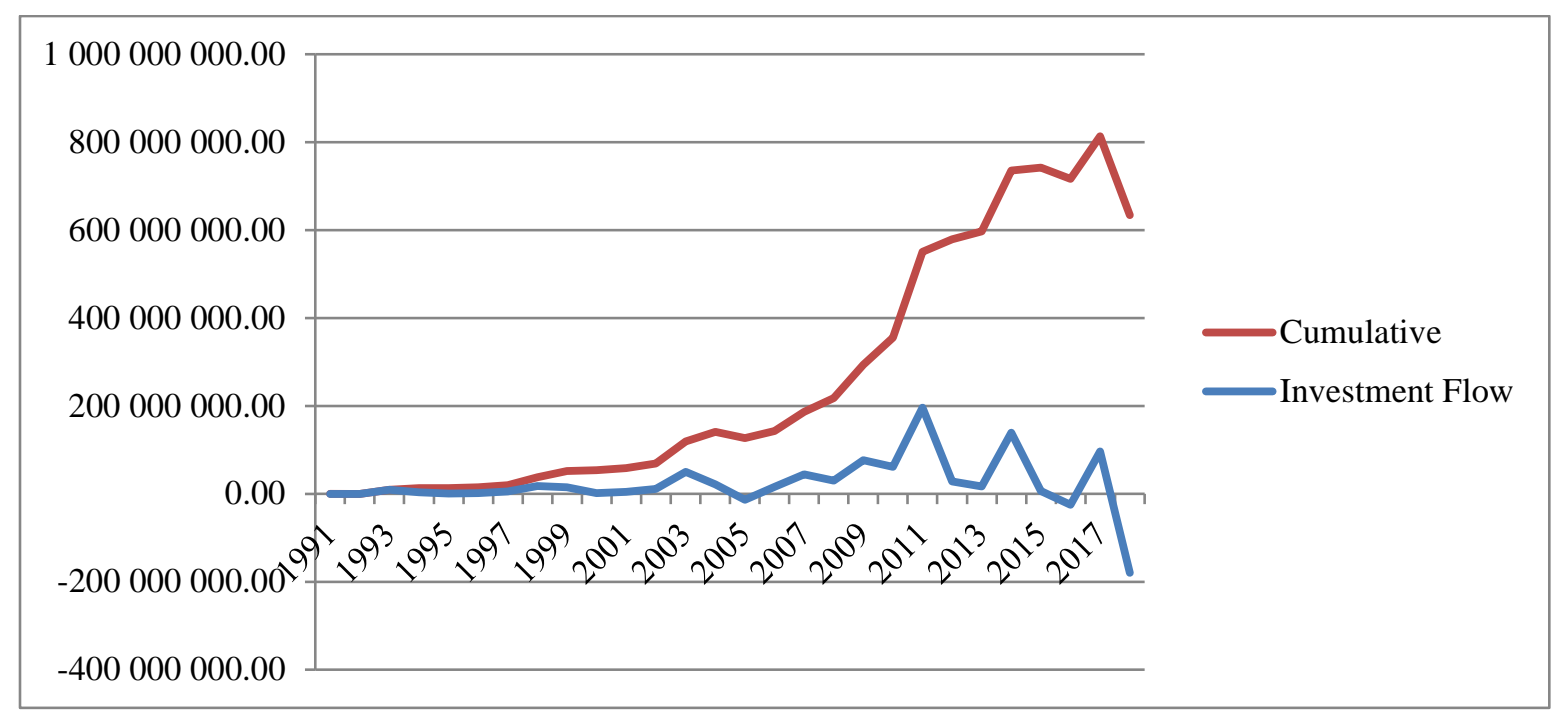

Figure 5 The Netherlands FDI in Latvia Cumulative and Yearly Flow, EUR (Lursoft)

In 2016 from JSC Ventspils Nafta, the record withdrawals of investments 145,271,321 euro 21.03.2016 and 61,212,895 euro was registered 10.08.2016 by Euromin Holdings (Cyprus) Limited. Despite Cyprus intermediation, the deals were registered as the Netherlands flow of FDI in Latvia.

In 2018, JSC European Lingerie Brands went through reorganisation 13.07.2018 and record withdrawal of investment by Myrtyle Ventures Limited of 39,935,000 euro was registered 13.07.2018.

For FDI from the Netherlands in Latvia, Sigma for the whole period 64866 031,16 euro, for the years 1991-2004 16356254,57 euro and for the years 2005201990264 483,23 euro.

Increase of FDI instability is evident for the third country of origin in this research. Following is analysis of FDI in Latvia from Cyprus (see Fig. 6). 


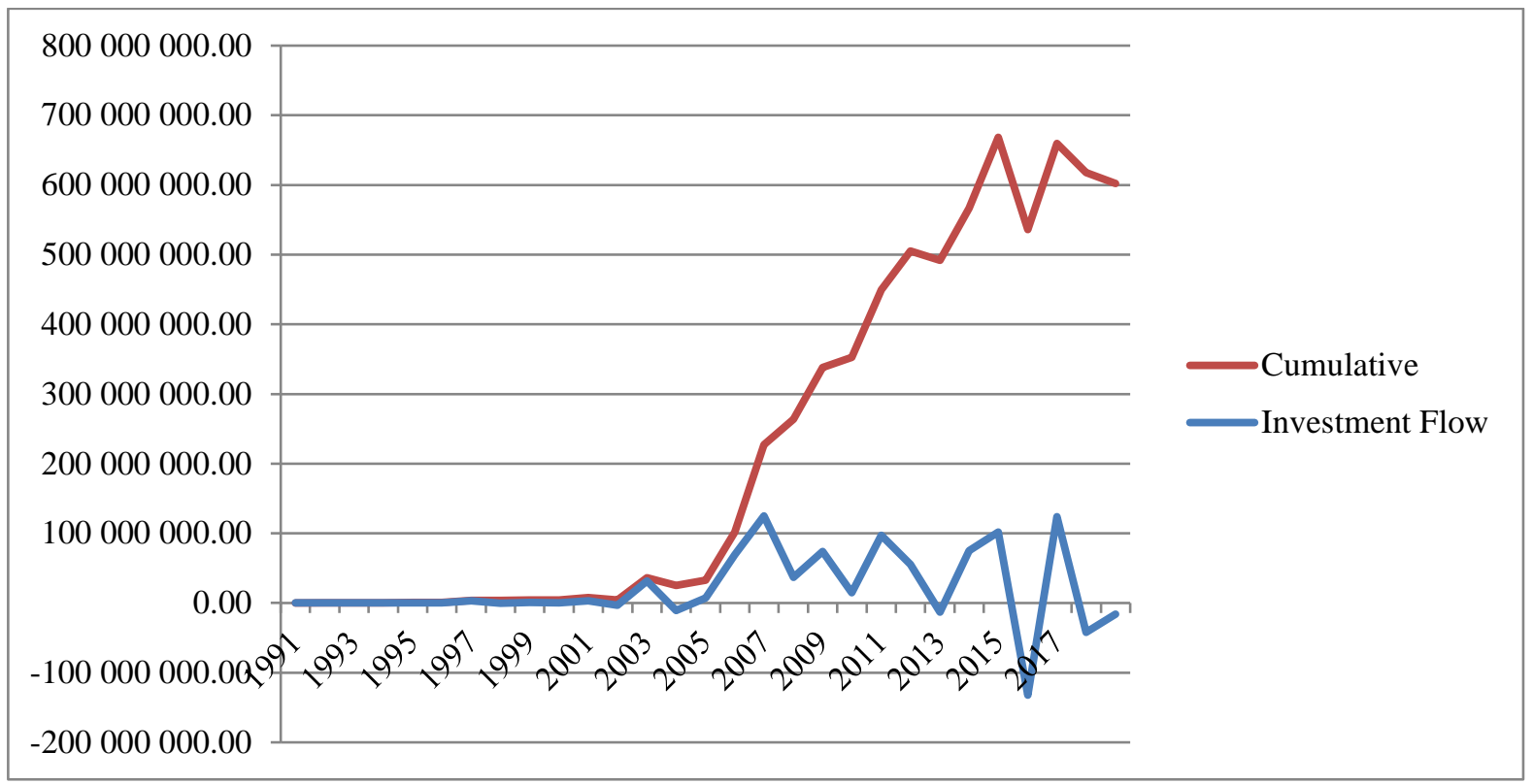

Figure 6 Cyprus FDI in Latvia Cumulative and Yearly Flow, EUR (Lursoft)

To investigate the abovementioned FDI by Euromin Holdings (Cyprus) Limited, it is notable that in 2007 "Ventspils nafta termināls", SIA received from this investor FDI of 54,759,933 euro registered 08.03.2007 as Cyprus FDI in Latvia. And next month more 19,523,358 euro was invested and registered as Cyprus FDI 01.04.2007.

Year 2007 demonstrated record increment of FDI from Cyprus in Latvia of 125,012,856.36 euro. Record withdrawals of Cyprus FDI from Latvia of 132255 086,47 euro in 2016 are registered on the name of the same Euromin Holdings (Cyprus) Limited.

For FDI from Cyprus in Latvia, Sigma for the whole period 57274 436,11 euro, for the years 1991-2004 Sigma is 9089 424,27 euro and for the years 20052019 it is 80486672,37 euro.

Increase of FDI instability is evident for the fourth country of origin in this research.

Following is analysis of FDI in Latvia from Lithuania, the last in the selection (see Fig. 7). 
Limanskis, 2021. Measuring Instability of Foreign Direct Investment Flows in Latvia

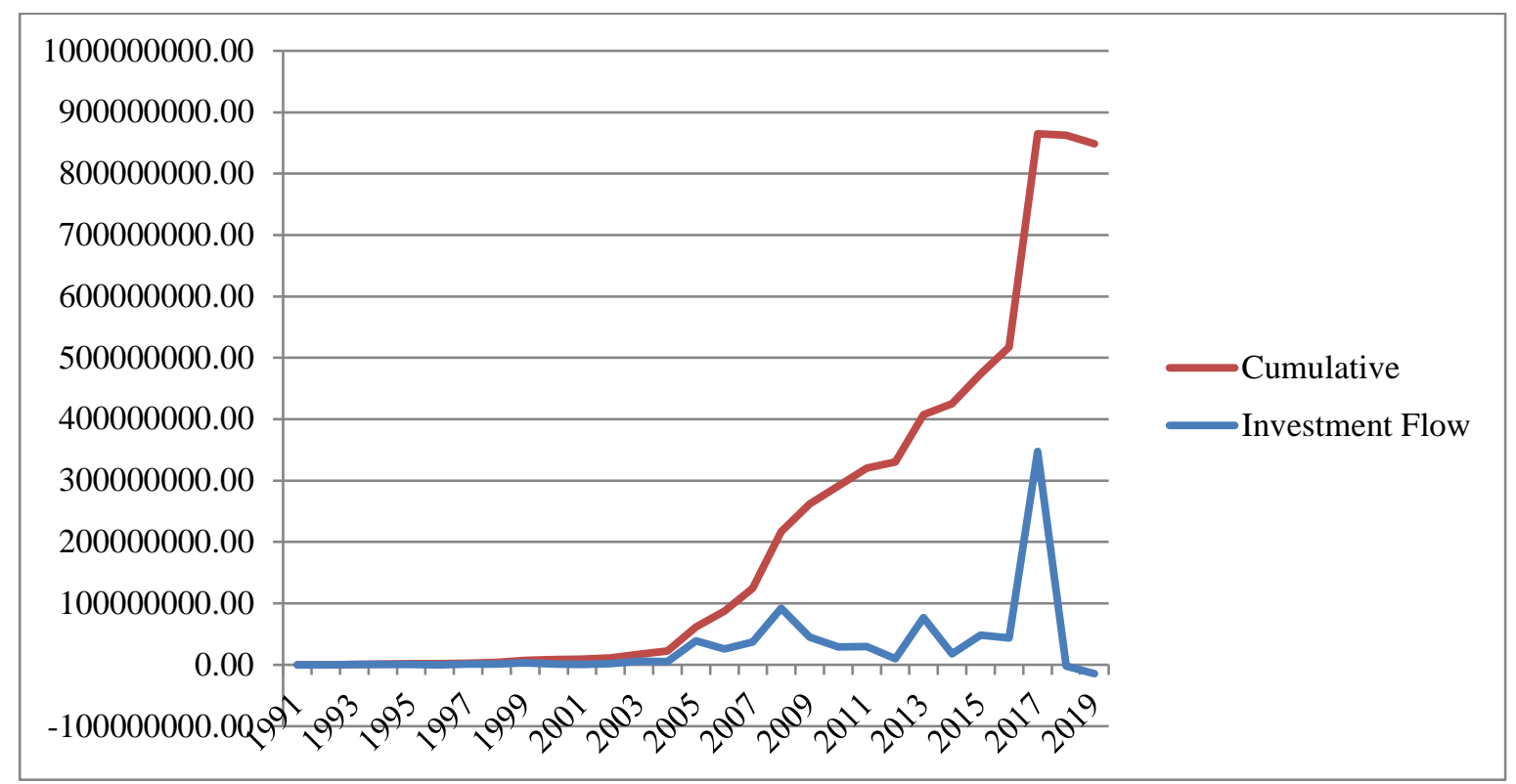

Figure 7 Lithuania FDI in Latvia Cumulative and Yearly Flow, EUR (Lursoft)

The case of Lithuanian DI in Latvia is unique. Among the top 5, FDI from Lithuiania grew negative only once in 28 years, namely in 2018. For DI from Lithuania in Latvia, Sigma for the whole period 31740 562,41 euro, for the years 1991-2004 Sigma is 2455 113,16 euro and for the years 2005-2019 it is 44820 743,23 euro.

Increase of FDI instability is evident for the last selected country of origin in this research. Following is generalisation of calculations (see Table 2).

Table 2 Sigmas for the the Two Sub-periods for Top Five FDI Flows in Latvia, EUR

\begin{tabular}{|l|c|c|c|}
\hline Country of Origin & $1991-2004$ & $2005-2019$ & Times \\
\hline Sweden & 33760697,93 & 337455184,96 & 9,99 \\
\hline Russian Federation & 20233929,49 & 68269533,51 & 3,37 \\
\hline The Netherlands & 16356254,57 & 90264483,23 & 5,52 \\
\hline Cyprus & 9089424,27 & 80486672,37 & 8,85 \\
\hline Lithuania & 2455113,16 & 44820743,23 & 18,26 \\
\hline
\end{tabular}

Source: Author on the basis of Lursoft statistics

It can be observed from the table that for all top five countries of FDI origin in Latvia in 1991-2019 Sigmas demonstrated significant growth in 2005-2019 against 1991-2004. Championing 18.26 times increase is documented for Lithuania and 9.99 times increase for Sweden. Cyprus and the Netherlands showed 8.85 times and 5.52 times increase correspondingly. FDI from Russsian Federation in Latvia demonstrated the lowest increase in Sigmas, i.e. 3.37 times, which means evident increase of FDI instability. 
Correlation coefficients between the total and the five top FDI volumes are presented in the following table (see table 3).

Table 3 Correlation Coefficients between the Total and the Five Top Volumes of Accumulated FDI in Latvia 1991-2019

\begin{tabular}{|l|l|l|l|l|}
\hline Sweden & Russia & Netherlands & Cyprus & Lithuania \\
\hline 0,928895 & 0,935072 & 0,973621 & 0,980864 & 0,899784 \\
\hline
\end{tabular}

Source: Author on the basis of Lursoft statistics

It can be concluded that all five are very strong correlations (above $0,899784)$. The strongest correlations, however, are discovered between the total volume and volumes of accumulated investments from Cyprus and the Netherlands in Latvia. They are followed by Russia, Sweden and Lithuania.

To finalise the analysis, Author singled out the years in which the FDI flow from the top five was negative (see table 4).

Table 4 Years of Negative FDI Flows in Latvia from Top Five Countries of Origin in 1991-2019

\begin{tabular}{|l|l|l|l|}
\hline Country & Years of negative FDI & incl. 2018 & other years \\
\hline Sweden & 5 & 1 & 4 \\
\hline Russian Federation & 5 & 1 & 4 \\
\hline The Netherlands & 3 & 1 & 2 \\
\hline Cyprus & 6 & 1 & 5 \\
\hline Lithuania & 1 & 1 & 0 \\
\hline Total & 20 & 5 & 15 \\
\hline
\end{tabular}

Source: Author on the basis of Lursoft statistics.

It can be seen in the table, that all top five donor countries suffered negative FDI flow in Latvia in 2018. Cyprus was champion with negative FDI in Latvia additionally in five years $(1998,2002,2004,2013,2016)$ followed by Sweden (2004, 2014, 2015, 2016), Russian Federation (1999, 2006, 2015, 2017) and the Netherlands $(2005,2016)$. Only five years of the total 20 belonged to the first time span in the analysis, while the vast majority 15 years were in the recent time span. It is an additional argument in favour of the general evidence produced by this research, namely increase of instability of FDI in Latvia.

\section{Conclusions}

The FDI instability in Latvia proved growing in 2005-2019 against 19912004. The corresponding sigmas increased in all FDI flows in focus sample of countries of origin from 3.37 to 18.26 times. 
Especially dangerous was 2018 when all top five FDI flows in Latvia found themselves in the negative zone.

Correlations between the total and the volumes of FDI that arrived from the five top donor countries are very strong, with coefficients above 0,899784 .

Growing instability is not to be tolerated. Measures are to be taken to diminish instability on political level and in corporate management. It is recommended to base attraction of FDI on sustainable growth model.

\section{References}

Cambridge English dictionary. (2020). Definition of instability in the Cambridge English dictionary. Retrieved from: https:/dictionary.cambridge.org/dictionary/ english/instability

Clive, W. J. Granger. (1994). Is Chaotic Economic Theory Relevant for Economics. A Review Article of: Jess Benhabib: Cycles and Chaos in Economic Equilibrium. Journal of International and Comparative Economics, 3, 139-145.

Dettoni, J. (2021). Covid-19 blows \$311bn in productive investment in 2020. Retrieved from: https://www.fdiintelligence.com/article/79396

Fingar, C. (2019). Inside fDi: SDGs can help FDI get over GDP break-up. Retrieved from: https://www.fdiintelligence.com/Inside-fDi/Inside-fDi-SDGs-can-help-FDI-get-overGDP-break-up?utm_campaign=Jan+2019+enews+2\&utm_source=emailCampaign\&utm_medium=email\&utm_content

Gandolfo, G. (2009). Economic Dynamics: Methods and Models (Fourth ed.). Berlin: Springer.

Investopedia. (2020). Definition of the standard deviation. Retrieved from: https://www.investopedia.com/terms/s/standarddeviation.asp

Leal Filho, W., Azul, A.M., Wall, T. et al. (2021). COVID-19: the impact of a global crisis on sustainable development research. Sustain Sci 16, 85-99. Retrieved from: https://doi.org/10.1007/s11625-020-00866-y

Lursoft. (2020). Lursoft statistics of FDI in Latvia. Retrieved from: https://www.lursoft.lv/ lursoft-statistika/Arvalstu-tieso-investiciju-sadalijums-pa-valstim\&id=501

Mathsisfun. (2020). Standard deviation formulas. Retrieved from: https://www.math sisfun.com/data/standard-deviation-formulas.html

Oxford Dictionary. (2020). Definition of instability in Oxford dictionary. Retrieved from: https://en.oxforddictionaries.com/definition/instability

Pelēce, D. (2020). Ārvalstu tiešās investîcijas Latvijā. Retrieved from: https://www.makroekonomika.lv/arvalstu-tiesas-investicijas-latvija

Research methodologists adphealth. (2020). Retrieved from: http://adphealth.org/ irtoolkit/research-methods-and-data-management/research-tools-andtechniques.html?tdrmodal=120\#sec4_1

Sauka, A. (2020). FICIL Sentiment Index. Retrieved from: https://www.ficil.lv/wpcontent/uploads/2021/01/ENG_2020_FICIL_Sentiment_Index.pdf

Your Dictionary. (2020). Definition of instability in Your Dictionary. Retrieved from: https://www.yourdictionary.com/instability 